\title{
The Missionary Reporter
}

\author{
MEGAN C. ARMSTRONG \\ McMaster University
}

Historiquement parlant, les auteurs franciscains nont jamais hésité à emprunter à d'autres genres littéraires lorsque leurs ordres du jour spirituels pouvaient en bénéficier. Il n'est donc pas étonnant de constater que les traités franciscains de pèlerinage en Terre Sainte imitent certaines conventions stylistiques et rhétoriques des relazione (relations). Ce que les frères mendiants ont trouvé de particulièrement utile était la façon qu'avaient les relazione de se concentrer sur le siècle, et simultanément de placer l'auteur en position d'autorité en tant que témoin expert. Les auteurs franciscains pouvaient employer le style de narration du temporel des relazione comme repoussoir à la description du royaume du Christ. Tout comme dans les relazione, les traités franciscains ont également souligné l'expérience personnelle des frères mendiants en mission dans la patrie du Christ. Ces deux stratégies fonctionnaient de pair, afin de réaffirmer pour les lecteurs européens éloignés le pouvoir sacré de la Terre Sainte, ainsi que l’autorité spéciale des frères mendiants en tant que vrais apôtres du Christ.

$\mathrm{T}^{\mathrm{n}}$ an age of practical reports of exploration to unknown places, early modern 1 European Franciscans persisted in composing meditative narratives of their voyages to the Holy Land. These writings had behind them a long pedigree of pious medieval accounts of pilgrimage. Their aim was not to inform the reader's mind but to awaken, remind, and ultimately transform, his heart and soul. To this end, Franciscan authors conjoined images of famous places with memories of central Christian moments, intent on provoking an emotional response. Their travel narratives were didactic in nature, marked not only by the rhetorical habits and moral traditions of the Franciscan order but also by its institutional ambitions. Franciscan narratives also celebrated the order's long guardianship of the holy places and its services to Latin pilgrims in the East. From the fourteenth century onward, it had been Franciscan friars who 
greeted European pilgrims stepping off the boats at the port of Jaffa, guided them through the streets of Jerusalem, and ensured the continuing celebration of the Latin rites at the most important Christian holy places.

Pilgrimage treatises such as these consequently bore only a superficial resemblance to the more culturally curious or scientific narratives or "relations" from pens of travellers to other parts of the world. ${ }^{1}$ But because they traced their authors' movements across seas and lands, they also borrowed literary habits from the evolving literature of travel. As early modern habits of reading, of writing, and of observing foreign places evolved, something of the spirit of the relazione began to mingle with the Franciscans' other narrative modes, producing as it did so a tension between two depictions, of things familiar and things novel. The relazione mode, as a literary device, invited the narrator to step in and mediate between matters astonishing, portentous, or novel, and a reader who needed not exhorting and moving, but convincing. At the same time, older Franciscan attitudes towards things of this world also made their literature fairly open to the relazione mode of writing. So new modes of knowing gradually pushed the Franciscan narratives of holy places towards a new synthesis, and a subtly mixed message, now only partly traditional in form but always thoroughly Franciscan.

From the start, Franciscan spirituality had a distinctly material cast, a worldliness that invited use of the relazione as a narrative device. Franciscan narratives confront us with the particularist nature of the early modern Catholic tradition, for their authors co-opted the pilgrimage genre to disseminate their own understanding of spiritual perfection. They stressed the continuing potency of the holy places in Palestine, a region that they had long come to consider as a foundation of their own authority as spiritual leaders. As with the relazione, Franciscan treatises privileged the author's experience in the Holy Land as the basis of his authority. Just as importantly, Franciscan authors could use the relazione-like narration of temporality - the condition of the mundane world - as the ideal foil for delineating the other-worldly nature of the homeland of Christ. These two strategies worked together, reaffirming simultaneously for distant European readers the continuing sacral potency of the region and the special authority of the friars as Christ's true apostles. Like Christ, their narratives say, the friars walked the frontier between the sacred and profane. 


\section{The Holy Land treatise}

Modern scholars do not find it easy to place early modern Holy Land literature. In her introduction to Jean Boucher's 1620 edition of Bouquet Sacre composée des plus belles fleurs de la Terre Sainte, Marie-Christine Gomez-Géraud ponders scholarly neglect of a treatise that enjoyed multiple editions over the course of three centuries. Lack of scientific and geographic specificity may well be one reason. Boucher's inclusion of a visit to Egypt that he himself never made, for example, earned the ridicule of at least one contemporary voyager. ${ }^{2}$ GomezGéraud, Wes Williams, and Frédéric Tinguely among others insist, however, that the Holy Land treatises must be viewed in part as collective enterprises. ${ }^{3}$ Medieval and early modern authors borrowed from one another, often repeating passages verbatim. Publishers, furthermore, felt little compunction about repackaging older treatises as recent works by adding, removing and rewriting sections at will. Imitation, as Williams has stated quite bluntly, was the point. Thus the pilgrim treatises differed substantially in function and narrative strategy from the relazione, a byproduct of the rigorous practices of Italian diplomacy.

A comparison of two well-known French narratives to the Levant illustrates the very different natures of these accounts. Relation d'un voyage fait au Levant (1665) recounts the nobleman Jean de Thevenot's journey to the Ottoman regions along the eastern Mediterranean. He begins by declaring travel a facet of the human condition. "The desire to travel," he tells us, "which has always been part of human nature, seems to have been never stronger than today...." Indeed, reading other relations "first gave me [Thevenot] the idea to travel." 4 Thevenot thus embarked on a journey inspired by a love of travel itself, and the Holy Land was only one of many important destinations discussed at length in his text. Meanwhile, Friar Jean Boucher's treatise also describes some of the places along his route, but does not provide the same degree of cultural analysis. His aspiration and that of other authors of Holy Land treatises was not to visit other people but rather to revisit the Christian past. These narratives situate the author as pilgrim, passing through exotic lands with his sights set firmly on the final destination, the homeland of Christ. This intense focus characterizes the very structure of the text, for as is typical for descriptions of the holy sites, Jerusalem alone takes up a third or more of the work. 


\section{The Franciscan Holy Land treatise}

But even Boucher's spiritual treatise reveals a certain familiarity with narrative and stylistic strategies closely associated with the more secular genres of relation. Indeed, a survey of Holy Land narratives shows that Boucher was by no means the only member of his religious brotherhood to find such strategies useful. This in itself should not surprise us. The very popularity of the relation ${ }^{5}$ as a literary genre would have appealed to the friars in their quest to reach an ever changing, and, they hoped, broadening, audience. Franciscans, preachers by formation, considered rhetorical flexibility critical to the spread of divine truth. From their earliest days, Franciscans had embraced changing literary tastes. That is one reason why their early modern libraries were so very eclectic. Even smaller communities might own, alongside medieval scholastic and devotional literature, humanist and classical writings, as well as scholarly works in Hebrew and Arabic. ${ }^{6}$ For example, the copy of Henri de Beauvau's Relation journaliere $d u$ voyage du levant (Paris, 1610) consulted for this article bears the autograph of a friar Bernardinus Talboon, and Beauvau's relation is a typical diplomat's treatise of the early seventeenth century, recounting a trip with the French ambassador to the Ottoman Porte. ${ }^{7}$

How, then, might the relation, as reporting model, have informed Franciscan pilgrimage narratives? The eight vernacular treatises discussed here were all produced between 1485 and 1670 . Some went through more than one edition and Boucher's Sacre Bouquet by early modern standards was a veritable bestseller. ${ }^{8}$ A cursory glance at these texts finds few overt signs of inter-genre influence. Direct references to contemporary secular travel accounts are largely absent. Not one treatise, furthermore, employs "relation" in the title. Indeed, the majority identify themselves through the traditional medieval pilgrimage terminology with traditional medieval titles: "treatise," "guide," or "voyage." The two earliest publications are Francesco Suriano's Trattato di Terra Santa (1526) ${ }^{9}$ and Jean Thenaud's Le voyage doutremer (circa 1525-1530). ${ }^{10}$ One sixteenthcentury account by an anonymous Spanish friar remained unpublished until the twentieth century and bears no original title. ${ }^{11}$ The Toulousan friar Henri Castela's Le guide et addresse pour ceux qui veult faire le S. Voiage a Jerusalem was published in $1604 .{ }^{12}$ The other seventeenth-century treatises include Jean Boucher's Sacre Bouquet (1620), ${ }_{13}^{13}$ Pacifique de Provins' Le voyage de Perse fait par pere Pacifique (c. 1631), ${ }^{14}$ Le pieux pelerin ou voyage de Jerusalem $(1666)^{15}$ 
by Bernardin Surius, and Jacques Goujon's Histoire et voyage de la Terre-Sainte (1670). ${ }^{16}$

As these titles suggest, the friars continued to locate their treatises in the long tradition of medieval pilgrimage literature. In recent years, whether mapping European religious culture on a broad scale, tracing an emergent subjectivity, or illuminating their distinctive rhetorical strategies, literary scholars have reclaimed pilgrimage narratives as a significant literary genre. But these writings sometimes borrowed from secular models, if only implicitly, to serve a spiritual agenda. Two questions immediately come to mind: What was the nature of this spiritual agenda? Is there, furthermore, something definitively "Franciscan" about this borrowing? This last question is particularly important in light of the erasure of Franciscan identity in much of the recent scholarship on Holy Land narratives. Erasure may perhaps be too strong a word, but it is striking nonetheless how little attention is paid to the religious formation of many clerical authors of pilgrimage treatises, including the Franciscans. One notable exception is Gomez-Géraud's work on friar Jean Boucher, but even here Boucher is viewed with a particular eye to Counter-Reformation spirituality. An extreme case is Wes Williams's rich analysis of French Levantine treatises, which seems largely unconcerned with the fact that two of his travelling authors - Henri Castela, and Jean Dublioul — were Franciscans. ${ }^{17}$

Early modern believers held that to join a religious order was itself a conversion experience, a conversion to a particular understanding of the Catholic tradition. Clearly therefore an important facet of these authors' identity has been left largely unexplored. Jean Dublioul serves as a good example. In his article "The Diplomat, the Trucheman and the Mystagogue," Williams sees Dublioul as a cultural mediator. Upon arriving at the Holy Sepulchre in Jerusalem, Dublioul introduces the reader to the "guardian" who then in turn attaches the reader to his spiritual guide for the visit, the "mystagogue." This guardian, though, is not just any "cleric" as Williams suggests, but the head of the Franciscan community living in the Sepulchre. ${ }^{18}$ The mystagogue is also a Franciscan, a senior member of Dublioul's own order. In this brief passage Dublioul is flagging his own particular Catholic identity. A layer of interpretation is lost when this Franciscan author is deprived of his habit.

It is a Franciscan mindset that similarly marks the eight travel accounts discussed here. To be sure, it was not the only ideological context. Franciscan 
authors were informed by other cultural forces, such as family, gender, and place of origin. They also disagreed in significant ways about their understanding of the Franciscan tradition. For example, all but one of the authors belonged to the Observant branch of the order. This was the largest of the three branches (Conventual, Observant, Capuchin), and the product of a fourteenth-century reform movement emphasizing stricter observance of the Franciscan ideal. The remaining friar, Pacifique de Provins, makes it quite clear in his text that he is a member of the Capuchin family known for its rigorous embrace of asceticism. Bernardin Surius's status as a member of the reformed Observant Recollect community also reminds us that diversity raged even within the separate branches of the order. ${ }^{19}$ Thus, despite a common Franciscan imprint, the eight treatises differ.

But if the authors were formed and informed by gender, family, and place of origin, and disagreed in significant ways in their understanding of the Franciscan tradition, they were, in the final instance, all Franciscans by formation. They shared devotion to the founder of their spiritual tradition, Francis of Assisi, recognized his Rule, and took the same vows of poverty, chastity, and obedience. And they had in common their order's special relationship with the homeland of Christ, for the Franciscans were the official custodians of the Christian holy places on behalf of the Western Church. In 1342, negotiations between the papacy and the Mamluk Turks secured official recognition of Latin altars in some of the most important Christian holy sites in Palestine, Syria, and Egypt. The epicentre of Christian worship for the pilgrim was Jerusalem, and the highlight of the pilgrimage was the visit to the Holy Sepulchre, the vast domed church first built by Emperor Constantine to commemorate the most important moments of Christ's final days on earth, his crucifixion and resurrection. In recognition of their century of missionary service in the region, in the bulls Gratias agimus and Nuper carissimae (Nov 12, 1342), the popes granted the Franciscan order the Custody of the Holy Land. ${ }^{20}$ This Custody would pass to the Observant branch in the fifteenth century. As it remains to this day, the primary role of the friars was to preserve a Latin presence in the region, perform the Latin rites for visiting European pilgrims at the major holy places and tend to the spiritual life of European merchants living in Jaffa, Aleppo and Cairo. ${ }^{21}$

The eight treatises show the authors busily engaged in the Holy Land over a span of some 180 years. The Venetian Francesco Suriano spent several years assigned to convents in Beirut and Jerusalem between 1480 and 1515. His 
French contemporary Jean Thenaud visited Cairo and Jerusalem as an envoy of Francis I in 1511-12. Internal dating locates the pilgrimage of the unknown Spanish friar sometime between 1550 and 1570. Henri Castela set out as a pilgrim from Marseilles in 1603. Two of his French countrymen would follow him within the next two decades: the famous preacher Jean Boucher (1611-1612) and the Capuchin Pacifique de Provins (1621-22). Pacifique, destined for a mission in Asia, visited the Holy Land as a pilgrim. In contrast, the Flemish Recollect Bernardin Surius and the French Observant Jacques Goujon visited in 1644-46 and 1666-68 as missionaries.

Religious tradition endows all eight Franciscan narratives with similar narrative form and intent. It explains why virtually all the treatises carefully delineate a Franciscan presence in the region, taking some pains to document the order's presence on the ground. For this task, the narrative strategies of the relation proved useful. Among other things, such writings privilege the training and experience of the author, as sources of his credibility. As Filippo de Vivo shows us in his study of Venetian relazioni, a relation was to be both informative and authoritative. The author's eye for detail, knowledge of local history, rhetorical training, and above all access to specialized knowledge through personal connections and experience were therefore on display. ${ }^{22}$ Jean de Thevenot's relation, for example, emphasizes the author's mastery of Persian, Turkish, and Arabic, languages that accredited his claim to local knowledge on his travels through the Mediterranean and beyond. Nevertheless, while lay travellers grounded their claims to expertise in their knowledge of the mundane world of human existence, the friars privileged their spiritual formation as followers of Francis of Assisi and their long custodianship of the holy places. It was Francis, they remind us, who made the mundane world of the Holy land his special mission.

\section{The author as spiritual expert}

\section{The mission of Francis of Assisi}

Francis did not visit Palestine until 1219, but his conviction that the homeland of Christ was the most important of all missions led the General Chapter meeting of the Franciscan order to establish the Holy Land as a Custody even earlier, 
in $1217 .{ }^{23}$ Francis's interest in rescuing the holy places was perfectly in keeping with his distinct brand of mystical piety, which accepted the mundane world as the natural site of spiritual reform. Just as, famously, he felt called by God to repair the little church of San Damiano near Assisi, the saint felt compelled to rescue the holy places from Muslim "corruption." The landscape and buildings that witnessed the life of Christ and his apostles held a spiritual potency useful for spiritual renewal. Though the failure of the medieval Crusades ensured that the Custody existed more in theory than in fact until the fourteenth century, the ideological construction of this region as a Franciscan missionary zone came over time to claim, profoundly, a kind of apostolic succession. As Franciscans readily reminded their readers, Francis received the wounds from Christ himself. He was the first great stigmatic saint, earning in his own lifetime the appellation alter Christus. ${ }^{24}$

Francis's stigmata and his time in Palestine underlay Franciscan claims to be the only true emissaries of Christ, who required spiritual engagement in His homeland. This assertion of an apostolic legacy is patent in the sixteenth century accounts. Francesco Suriano reminds his readers that Francis himself trod in the footsteps of Christ. Like Christ, Francis visited the Holy Land, and like Christ he also pursued a wandering preaching ministry. Referring to himself as the "putrid member of so great a head," the Venetian friar tells us that Francis "never ceased to run hither and thither and to travel far and wide to gather men faithful to God and his fruitful Church." ${ }^{25}$ As far as Suriano is concerned, only the followers of Francis could provide spiritual guidance. Moreover, their greater perfection justified Franciscan care of the holy places. To support this jurisdictional claim, Suriano cites plentiful Franciscan miracles, many of them from Beirut in the 1480s, which occurred during his first mission. So he was himself a witness to the potency of Franciscan spirituality. We discover that praying to Saint Francis had aided the escape of a Muslim sailor when the Knights of Rhodes threatened to take his ship. In another miracle tale, the friars had only to touch trees to make them fruitful. Such miracles - and there were many more, the friar assures us - amazed the "infidels" and earned respect for the Franciscan tradition. "And the extraordinary thing," Suriano tells the reader, "is that they do not suspect us of evil, nor are husbands scandalized if we are seen talking with the wives: this is something they do not allow their own co-infidels."26 
When asserting apostolic succession, Surius and Goujon, in the seventeenth century, are even more vehement. The Fleming, Surius, describes the friars as "children of our father Saint Francis, who are known throughout the land for their influence... and charged with the well-being of Emperors and Kings." ${ }^{27}$ While on his journey across Europe to the Holy Land, Surius stops to worship in Assisi, the home of Saint Francis. This visit invites him to meditate on the perfection of Francis by mulling on key episodes in the saint's life. Surius recounts Francis's reception of the stigmata, but he also describes the cell where the saint stayed during this momentous transformation, and ponders its significance. Francis becomes, in the process, absorbed into the Holy Land experience for both Surius and his readers. The saint's life is now part of the spiritual itinerary of the pilgrim. The stigmata signal, furthermore, what the Franciscans have always believed, that Francis's life was the only legitimate gateway to the spiritual perfection embodied by Christ.

This fashioning of Francis as the perfect spiritual guide to the Holy Land explains why Surius's seventeenth-century contemporary, Jacques Goujon, makes Francis's mission to Palestine the mental and literary starting point for the entire journey, as he narrates it. Francis had a special zeal, he tells us, for the Holy Land because of his "perfect love" of the suffering and passion of the crucified Jesus." Rescuing the Holy Land from the "tyranny of the Mahometans" was always his concern. For Francis, to do so was to imitate Christ; on his journey to Palestine, we are reminded, Francis brought twelve companions. It was God, Goujon says, who made the friars the "inheritors of the Holy Land, because he wanted this seraphic father [Francis] to take possession." Possession is Goujon's issue, for Francis emerged from his pilgrimage with the guardianship in hand: "[the Holy Land] became his possession and all the holy sites he visited belonged to him." Goujon reminds readers that Francis was first and foremost a spiritual reformer, sent on earth with a mission to cleanse the thirteenthcentury church of corruption. It was a place of "rot, filth, and idolatry, and a shameless Venus: and Saint Francis was chosen to end these disorders." ${ }^{28}$ Christ had to return to heaven, Goujon says, and so gave Francis responsibility for leading this reform. Francis was the ideal choice, he says, because he was "the most perfect, and the most vibrant image of the suffering Christ." ${ }^{29}$ And Francis, assuming responsibility, had been chosen to reclaim the sites as well from their infamously fallen state. 


\section{The experience of the friar}

This evocation of Saint Francis as spiritual reformer charged with responsibility for the holy places anchored Franciscan claims not only to custodianship but also, even more importantly, to spiritual expertise. Goujon's reminder of Francis of Assisi's war against corruption during his own lifetime was intended to resonate with seventeenth-century readers who had experience of spiritual turmoil. Just as Francis battled heresy in Europe and Muslim authority in the eastern Mediterranean, his seventeenth-century followers struggled to eradicate Protestantism in Europe, to reform "pagan" traditions in the New World, and to preserve Christian spirituality from Ottoman pressure in early modern Palestine. No other Christians, the friars felt, had so deep an understanding of the Holy Land's meaning for their own struggles at home, because of Francis's intimate connection with Christ and His homeland.

This explains why Franciscan regulations granted access to the region for all willing members, ${ }^{30}$ a privileged access that explains why friars so often figured as travellers, pilgrims, missionaries and even political envoys, and also why our Franciscan authors believed their accounts of the region had special spiritual merit. Franciscan treatises informed readers on the title page that the author was no simple voyager but a Franciscan brother or father ("fra," "frater," "frère," "reverend père"). Early modern readers understood that some brothers were more equal than others: possessors of high convent office or a theology degree from a Franciscan studium or, even better, a university doctorate. ${ }^{31}$ The elite were the first to be chosen for prestigious missions like that to the Holy Land.

Jean Thenaud, as his treatise shows, was a typically accomplished pilgrim. On his return to France, he would enjoy an illustrious career as an author. Indeed, before his voyage of 1511, Thenaud had already published a book, $L a$ marguerite de france (1508). ${ }^{32}$ The title page of his treatise identifies him as a Master of Arts and guardian of the convent of Angoulême. In the preface we learn that his journey eastward was first and foremost a political posting, in the service of the count of Angoulême, the future Francis I (d. 1547). Wishing to know more about the Ottoman court and Persia, the count had relied on Thenaud for insight. Like other Europeans, Angoulême was both fascinated and perturbed by the spread of Ottoman authority. Indeed, only a few years after Thenaud returned from his visit to Palestine, the Ottomans would seize 
control of Palestine and Egypt. ${ }^{33}$ But Thenaud also received another political charge, from Louis XII himself. He was to accompany an embassy to the sultan of Egypt, to secure the release of the French consul and the friars of the Holy Land from imprisonment. The friars and the consul were casualties of the struggle for supremacy in the Indian Ocean between Portugal and Egypt. Thenaud's stature as a prominent French Franciscan might explain why the king thought his presence useful. ${ }^{34}$

Thenaud, a highly educated friar, enjoyed the confidence of some of the most powerful men and women in France. To invest his account with gravity and political clout, he cited a royal exhortation to write things down. But, as an envoy, Thenaud moved fast. A missionary, posted for three years or more, would have had longer experience on the ground. Even ordinary pilgrims stayed up to eighteen months, the voyage itself being so hard and long.

Long years in the Holy Land and care of the sites pointed to another level of spiritual expertise: they explain why the majority of our authors were missionaries. Thenaud's Italian contemporary, Francesco Suriano, spent several years as a missionary in the Holy Land, from 1480. Trattato di terra santa, first published in 1485, mostly concerns his first visit to the region, but later editions would also incorporate observations from his two stints as guardian of the main Franciscan community in Jerusalem (1493-95; 1512-14). Although Suriano writes his work as a dialogue with his sister, he has in mind not his sibling but his reader when he parades his own qualifications as expert witness. The scene set by Suriano's dialogue is intimate. He visits his sister, Suor' Sixta, at her convent in Foligno after his first return from the Holy Land in 1484. The dialogue's two personae treat each other warmly, but Suriano affirms that their shared love of the Franciscan tradition defines their relationship. Both belong to branches of the same order: Suriano an Observant, his sister a Poor Clare. His "little treatise," he claims, was produced at her request.

In his narrative, Suriano takes his sister on the standard visit to the holy sites, but also regales her with tales celebrating the friars' local works. Sixta interjects now and then, mostly to ratify Suriano's authority. Following his account of the Franciscan miracles during his mission to Beirut, for example, Sister Sixta suggests that Suriano himself bears the visible marks of spiritual perfection because of his missionary work in the Franciscan tradition: "The perfection of the Seraphic Order is worthy of greater veneration," she exclaims. "That infidels have such devotion and faith I believe to be caused by divine 
illumination or by some singular virtue and perfection of life which they see reflected in you continually." Much later, Suriano's description of living on raw beans and "stinking" water while sailing back to Italy will prompt Sixta to reassure him of a divine reward: "I believe, my most beloved brother, that you have accumulated great merit before God for the great exertions and fatigues you have borne out of love for him by your ready obedience and by the service you have rendered in governing for so many years those glorious places, treasures of God on earth, which all the faithful desire to see and kiss." ${ }^{35}$

Missions and pilgrimages indeed tested the spiritual worthiness of their practitioners, and by the sixteenth century the mission was also indelibly associated with martyrdom. Missions ought to be difficult, and should involve travail and suffering. As with many Franciscan treatises, Suriano reminds us that the missionary labours in a hostile land. In his account of his visit to Mount Tabor, for example, Suriano recounts an attack by robbers during the Latin rites. The incident ended peacefully, much to his relief. For the first time in 300 years, he tells us, Catholics could celebrate at this site without much danger. ${ }^{36}$ But danger was an ever-present reality. Franciscan accounts, Suriano's included, record acts of violence ranging from Bedouin assaults on pilgrim caravans, to the imprisonment and torture of friars by Muslim authorities. Suriano found his second stint as guardian particularly trying. During his first guardianship (1493-95) the friars benefited from warm relations with Cairo's ruler, Kait Bey (1468-1496), who had spent some time as a rebel prisoner in Jerusalem prior to becoming Sultan. ${ }^{37}$ The Muslim sovereign protected the friars, and even let them rebuild their sites when "all Jerusalem and almost all of Cairo were opposed to it." ${ }^{38}$ By 1512, however, when Suriano returned to the office of custodian, the political situation had changed dramatically. His immediate predecessor, Bartolomeo of Piacenza, was one of the friars imprisoned in Cairo whom Jean Thenaud intended to visit. The charge against Bartolomeo and the other friars, according to Suriano, was extortion. The brothers stayed in prison for several months before negotiations freed them.

Tension continued to define relations between the friars and the new ruler. As the friar tells us bluntly, "it seemed to me very fatiguing and hard when I remembered the immunities of my first guardianship, for the old troubles, swindles and extortions and unbearable burdens had returned." ${ }^{39}$ But Suriano would face other challenges to his governance, no less taxing. As throughout early modern times, wrangles with the Greek Orthodox, Armenians, and Copts 
over access to the holy places were tense and volatile. These struggles were at times quite violent. ${ }^{40}$ Suffering on behalf of their mission, of course, only ratified the calling of the friars as Christ's servants. Christ's crucifixion made such suffering a route to spiritual enlightenment. Suriano had proved himself not only a devout servant of God but also a bearer of authentic spiritual knowledge, thanks to his travails.

How far then is Suriano's dialogue, in voice or tactics, from the relation of a Venetian ambassador? Like the relation, it privileges the reporter's voice, and uses his experience, as witness, to give the text authority. And, like the relation, it does attempt to lay out conditions on the ground. As a piece of writing, however, his dialogue is only half-kin to the relation mode. Ultimately, Suriano's discussion of local conditions is not concerned with building a precise and informed understanding of the region but rather ratifying his authority as spiritual interpreter. Experiencing the hardship of the missionary life in the Holy Land served to deepen his understanding of this region's special nature.

A similar assumption about the greater spiritual knowledge of the missionary no doubt explains why in his well-known Bouquet sacre, Jean Boucher (d. circa 1631) is so quick to distance himself from being labelled an ordinary pilgrim. Boucher informs us that shortly after his arrival in Jerusalem in 1611, the guardian invited him to preach at Easter in the Holy Sepulchre. The invitation came after a series of conversations about theology and other serious matters that, according to Boucher, so impressed the guardian that he asked the French friar to become the preacher. During Lent and Advent, Boucher preached in the main friary and the Sepulchre. ${ }^{41}$ To preach where Christ spent his final days was no small honour, but Boucher's experience was in some ways atypical. He was by his own account a success, and stayed six months. ${ }^{42}$ Joining this mission impromptu, even temporarily, was unusual. Normally, missionaries were carefully selected by Franciscan officials from provinces across the Franciscan family, and vetted by the Minister General and his colleagues in Rome. ${ }^{43}$ Missionaries almost always had a university education and likely several years of administrative experience in their convents.

The seventeenth-century missionaries Bernardin Surius and Jacques Goujon fit this profile. The approbation given by the provincial minister of the Flemish Recollects to the 1663 edition of le pieux pélerin notes several offices of friar Surius: priest, preacher, confessor, guardian, and perhaps most importantly of all, apostolic commissioner of the Holy Land. This last appointment, 
in 1646, two years into his mission, shows that in Palestine Surius continued to hold high posts. Whether Goujon occupied an office while on mission is unclear, but his preface notes that he is a university-trained preacher who has worked closely with the apostolic commissioner of the Holy Land, Francesco Maria Rhini, at time of publication the new Minister General. Goujon clearly felt that his personal association with so illustrious an official vouched for his own stature. In his address to the reader, Goujon praises Rhini for his diligent protection of the holy sites: "you [Rhini] appeared in these holy places that I describe like the true inheritor of the authority and poverty of our illustrious Patriarch." Goujon tells us, furthermore, that he can testify to this from personal experience: "My Heart witnessed for over three years with what sanctity and zeal you preserved these sites." ${ }^{4}$

In one brief passage Goujon not only praises Rhini but also underscores his personal association with this important cleric. Goujon stresses, furthermore, that he himself spent over three years living in the region, working first in Jerusalem, Bethlehem, and Nazareth, and later in Egypt and Syria. These years spent travelling around the custody gave him rich insight into the special nature of the homeland of Christ, he argues, and so he scoffs at treatises published by mere pilgrims. "I marvel," he says, "how our pilgrims who write long volumes of the Holy Land, after at most their month-long visit, believe that they can explain everything that there is to it." ${ }^{45}$

\section{Narrating the mundane and divine}

In the skillful hands of our authors, the Holy Land takes on decidedly Franciscan contours. The reader-pilgrim moves from site to holy site with Franciscan guides, takes the sacrament from friars' hands at Latin altars, and, at day's end, retires to a Minorite hospice. At every step he cannot but feel the founder's presence. The friar authors, imprinting the Franciscan tradition on this landscape, claimed, de facto, their order's role as mediator between Christ and both the reader and all other Latin pilgrims.

It is here that the influence of the Italian relazione and the other more secular-minded relations upon Franciscan construction of the Holy Land as a sacral space becomes apparent. Christ may have lived on the frontier between the sacred and profane during his lifetime as the incarnate son of God, but 
the friars relied upon their intimate understanding of his worldly homeland to disseminate his message of salvation. All good Christians knew that the Holy Land was infused with Christ's perfection. But true understanding of Christ's message required both the correct mindset and an immersion of oneself in this perfection. The material cast of Franciscan spirituality is particularly pronounced in their discussions of the spiritual potency of the landscape; readers were reminded that spiritual perfection must be pursued in the earthly realm of existence. "I am a simple pilgrim," friar Surius explains with expected Franciscan humility; he makes no claim to expertise in "cosmography, nor geography, nor geometry." He does emphasize, though, that he has visited the sites personally, and that he did so with "a curious devotion and a devoted curiosity." His use of the term curiosité in this context underscores that his journey is one of a spiritual enlightenment and not strictly introspective, but open outward to a variety of experience. Visiting the land was itself efficacious, but perceiving the fullness of its meaning required special knowledge and training.

His spiritual formation as a Franciscan made Surius a valuable interpreter for his readers precisely because of the order's long and intimate relationship with the homeland of Christ. ${ }^{46}$ His treatise is not, strictly speaking, a relation, but it shares with that genre the introjection of the author, who stresses his foreign expertise and direct experience, as an authoritative mediator of a distant place with special traits. Not only Suriano, but also other Franciscan authors used a variety of devices to anchor their meditative sacred visits. Often, it was in the relation's celebration of the quixotic and changing nature of the mundane world that the friars found strategies useful for their spiritual purposes. We see this most plainly in the narration of the journeys both to and from the Holy Land. Here, in these framing sections, our friars play with both space and time to illuminate the otherworldly nature of the homeland of Christ.

\section{Movement and space}

Older Franciscan narratives of pilgrimage paid scant attention to the details of the journey east. A desire to convey the other-worldly nature of the holy places explains why traditionally Holy Land treatises took a thoroughly liturgi$\mathrm{cal}$ form. These treatises locate the visitation of the holy places in Jerusalem at the very heart of the narrative. Much like a worshipper performing the Stations 
of the Cross in a parish church at Easter, the reader pilgrim travels with the author-friar through the last days of Christ's life. The physical description of the site is itself an important part of the narration, like the recitation of the relevant Biblical story and the appropriate prayers. Equally important is the attitude of the pilgrim who must pause and meditate at each stop along the journey. The more detailed discussion of the sites always stands in contrast to the relatively simple, even perfunctory descriptions of the journey to and from Jerusalem, and even between the sites themselves. It was visiting Christ and contemplating his life that mattered.

As Suriano's description of the visit to the Holy Sepulchre shows, the recounting of the liturgical rites was intentionally transgressive. His description of the celebration collapsed spatial boundaries to bring the distant pilgrim reader in direct emotional contact with the living Christ. ${ }^{47}$ After first providing a detailed physical description of the site and relating the relevant biblical story, Suriano asks his sister Sixta to "join" in the procession of the friars and pilgrims as they file through the massive structure. Suriano's use with his sister of verbs in the present tense, or in the hortatory voice, collapses the distance between the sites and the Christian reader still at home. Sixta and her sisters at once become part of the procession, filing two-by-two alongside the other pilgrims. The abbess, he tells us, will be their standard bearer. The description of this visit continues for several pages, working all the reader's senses. The sights and sounds of worship are particularly important for Suriano, who recognizes that true contrition requires the softening of the sinner's heart. As the pilgrims enter the Franciscan chapel, for example, Suriano signals the singers to begin their chants. The chanting becomes the cue for lamentation as the pilgrims themselves experience the suffering of Christ in his last days: "And as the friars begin in our chapel," he informs us, "in like manner let the chantresses begin, inviting all to weep and lament in participation of the pains of your spouse Christ, the only Son of the Virgin Mary, Master of Magdalen and the other Marys, underwent at the time of his passion, crucifixion and burial." 48 The visit then ends with a recitation of the appropriate prayers and a description of the indulgence allocated to the site.

This liturgical form will continue to shape later Franciscan accounts as well, but in the journey to and from the holy places the friars, as a relation would, provide more detailed descriptions of the lands encountered along the way. The treatise by the anonymous Spanish friar (circa 1550) is just one exam- 
ple. On the road to Damascus from Levantine Tripoli, for example, he records Maronite churches around Mount Lebanon and sketches their religious organization and relationship to the Catholic Church. He then describes the route through the mountains, taking note of the cedar trees, climate, and population. As the friar leaves behind the mountains he makes the following characteristic observation: "Thence, passing over Mount Lebanon, which is always overcast in many parts throughout the year, and is very high at the summit, we descended on the other side towards the foot of the mountains and came to the village of Apueta, in which dwell Moors and Christians." ${ }^{49}$

In the passage above, the Spanish friar's narration shows greater attention than do earlier pilgrim tales to the cultural and physical landscape along the way. The seventeenth-century Franciscan texts are even more detailed. Typical is the account of the Toulousain Henri Castela. Castela sets sail from the port of Marseilles sometime before 1604, and from there engages more with the sights and sounds of the regions he visits than do earlier authors. Castela's nonstop commentary alternates between disdain, wonder, and even fear. He begins with practical information on sea travel, and describes his fellow voyagers. His description of life aboard the ship to the Holy Land conveys the sailors' and pilgrims' fears of storms and piracy. We learn, for example, that passengers could retreat to a special space on the ship where the sailors stored their "bell [clochette] and the images that they worship of our Lord, his mother the glorious virgin, and of some other saints." Here in this makeshift chapel they could be heard "every night praying and expressing their zeal for God." ${ }^{50}$ Once on shore, the friar marvels at a cosmopolitan world in which Turks, Arabs, "Moors" and the different Christian groups share space in hospices and holy sites along the way. As in many Levantine narratives of the early modern period, Cairo receives extensive treatment. ${ }^{52}$ Castela remarks that Jews and Muslims shared religious buildings, unlike the Protestants of Europe who wrecked their rival's churches. The comment, while shallow and tendentious, does show an eye to local facts. ${ }^{53}$

As Castela approaches the Holy Land, his geographic frame grows richer, evoking both spatial and cultural dislocation. His several ruminations on the Mediterranean world convey movement through space. Here and there he pauses to comment on his surroundings before resuming the road to Jerusalem. The pace is fairly rapid, even so, as Castela rarely dwells for very long on what he sees around him. This feeling of movement, when combined with the con- 
stant flow of information provided by his commentary, brings to the journey a temporal immediacy little seen earlier in Thenaud and Suriano. We feel that we are walking the road alongside Castela, experiencing our own first encounters with the colourful and diverse populations of the eastern Mediterranean.

Castela's effort to capture the sensory experience of movement through the Mediterranean world served a reformist agenda aimed at heightening the spiritual potency of the holy places. Relation narrative strategies conveying cultural and political information may have helped the Franciscan treatise to demarcate this world from the next. The pilgrim's journey takes him from the bustle and chaos of the mundane world to the coolness, calm, and the pleasant odours of the holy sites. Because of the traditional tripartite division of Holy Land narratives - the journey to, visitation, and return home - this narrative demarcation of the mundane and the otherworldly did not require any great change in the structure of early modern Franciscan accounts. It did, however, require greater deliberation on the day-by-day journey of the friar to the region. The friar's own experience of the holy places was no longer the sole thing worthy of the reader's eye.

The friar's physical movement through space is even more powerfully evoked in the account by Surius. In a nod to the relazione genre, Surius states his intent to describe the different peoples "outre-marins" as much in "the matter of religion" as in "administration." 54

The primary intent, though, is religious. His text describes the history of the region and the holy sites in particular to "stir religion" in the pilgrim's heart. More than the other authors discussed here, Surius lays out his journey from home. His pace is perhaps less hectic and more stately than Castela's, as he and his companion make their deliberate way to Marseilles. Walking through France in 1644 was dangerous because of the presence of soldiers; France was still enmeshed in the Thirty Years War, and as a subject of the King of Spain Surius was unwelcome. He and his companion lacked passports, and at least once barely escaped arrest. ${ }^{55}$ The friar fully evokes his clandestine, anxious journey. Yet fear of capture did not dissuade Surius from noting his surroundings, as he wandered through villages and towns, staying in monasteries and visiting churches all along the way. His observations on the state of France are at times cursory, though now and again he does comment on current events. On the border between the Low Lands and France, Surius sadly notes war's havoc: "I look at all of these desolate places with a very sad eye, the frontier lands both in 
the Low Lands and France entirely ruined, churches burned, castles razed, and villages abandoned, the pitiful results of war." ${ }^{56}$ Later on his journey southward, just outside Lyon, Surius mentions the hardships of villagers who had suffered from a recent frost on the vines and who also complained about the king's harsh taxes. His account corroborates growing dissatisfaction with the monarchy by the 1640 s because of its excessive exactions on the peasantry. ${ }^{57}$

\section{Time and timelessness}

Such mundane elements ground the friar's treatise in a particular time. Surius also names the men and women he encounters during his travels, yet another device that anchors his text in the 1640s while conveying movement through the French landscape. ${ }^{58}$ Over and over Surius responds to what he saw and heard at each place, a narrative strategy reminding readers that the journey is occurring in their own lifetime as well. Surius also takes care to mark his journey by the days of the calendar.

The rapid movement conveyed by the first part of the treatise stands in deliberate contrast to the much slower pace of the pilgrim once near the Holy Land. Other treatises make the same transition. At times this shift in pacing is jarring. Once on the doorstep of Jerusalem, the epicentre of the holy, Jean Boucher stands stock still to expound on the city's special sanctity. His Sacre Bouquet (1620) mingles narrative and elegiac literary forms far more than do the other early modern Franciscan treatises. His lengthy exposition requires a break from the journey described thus far. The description becomes more lyrical and more deeply felt. The busy-ness of the outside world falls away, allowing an altogether different kind of journey. Boucher's ode to Jerusalem also laments the pitiful state of the city. In noting the need for material restoration of the holy places, the tone is traditionally Franciscan and very mindful of the legend of Francis rescuing crumbling churches. Anxious to view the glorious home of Christ, Boucher conveys his disappointment at its actual dilapidated state: "But alas! My hopes were vain and mistaken, because I found a city... enshrouded in shadows, ruined of its glory and honour...." ${ }^{59}$ He nevertheless emphasizes its special beauty, untouched by the "infidels" who occupied her land.

By the seventeenth century, Holy Land treatises habitually bemoan the state of a captured Jerusalem in Muslim hands. Scholars have viewed these la- 
ments variously as reflections on the broken nature of the post-Reformation Christian body, defenses of the efficacy of the pilgrimage, and even as signs of emergent subjectivity in early modern texts. ${ }^{60}$ The great emotion of such descriptions reminds us that Franciscan preachers sought to instill spiritual reform by stirring an emotional response in their Christian readers. Jerusalem, like the soul of the sinner, was imprisoned in an imperfect body. Typically Franciscan, Boucher viewed the world as simultaneously a site of human redemption and corruption. ${ }^{61}$ So he never portrays the world outside the doorstep of Jerusalem, let alone Jerusalem itself, as wholly decayed and ruined. As Francis of Assisi insisted, the life of Christ incarnate marked the Christian path. Like the human body, the world was material not immaterial, and thus in constant decay. The world was at once a glorious creation of God, and the source of serious temptation. It was, more to the point, an inconstant, unstable place. Whereas the heavens existed outside of time, the world was a slave to it. And yet, living at the heart of this inconstant and corrupting reality, the sinner could hope to seek perfection. For Boucher, the holy sites were mired in the filth of sinfulness but their true beauty could not be quenched. Boucher's emphasis upon the timeless and constant nature of the holy sites thus underscores the inconstant and potentially corrupting nature of the human world around it.

Returning to Bernardin Surius, we find a similar narrative demarcation of the sacred and profane. For Surius, however, it begins much earlier on his journey. Observe his description of the visit to the church of Saint Maximinla-Sainte-Baume in Provence, dedicated to Mary Magdalen. Here, according to apocryphal accounts, the saint spent 30 years in contemplation after leaving Palestine. Arriving at this special place, Surius lets us know pointedly that he is stepping off the road to seek rest ("repos.") His visit lasts ten pages, and the accompanying lush, sensual description and slower pace makes it clear that in veering off the mundane road he has ventured into a different realm of existence. Entering through an iron door, Surius is immediately overwhelmed by the beauty of the saint's grotto. His description dwells on the rich ornamentation, all gifts of well meaning patrons: silver lamps, a bed made of the softest Dutch feathers and Cypriot wool, an embossed image of the Magdalen. This place, he exclaims with an eye for landscape, "is the most admirable in the world, as much for its solitude and height as for the penitence of the saintly lover of Jesus who found contentment here."' ${ }^{2}$ Surius conveys the ecstatic nature of his own experience, urging the reader to transform his or her own chamber into a 
similar "grotto" to be alone with God: "You should do this two times a day, find a place to be alone, to pray, to think of God." ${ }^{3}$ The friar describes the hermitage itself as a "cabinet" of divine love. His depiction of it as a site of solitude, peace, and love identifies this space as a fragment of heaven, and also of Palestine, on earth. The cabinet cell described by Saint Bernard is none other than "a little Paradise: from the cell, one climbs to the heaven, the cell is a holy land and a place where the soul joins with God." ${ }^{4}$

\section{History}

Creating one's own cell or "cabinet" for contemplation - whether a literal or internal space - aided a Christian's resolve by establishing amid daily existence a place for the sacred. The experience Surius describes in this grotto is ecstatic, reflecting the mystical cast of Franciscan spirituality. The pilgrim is at once one with God, transformed, and lifted out of the dross of mundane existence through immediate and intimate contact with divinity. Locating the grotto along the journey to the Holy Land situates the sacred in the midst of the profane, as the soul is in the body and the church is in the world. In describing the grotto as a place of repos though, Surius is also evoking the otherworldly character of sacral space. The grotto of Mary Magdalene is a "paradise." It is itself a "holy land." At such a site, heaven brings earth up to meet it, and earth joins the eternal realm.

Such repeated straying from the path of mundane existence into the realm of the divine has already prepared readers for what they will find in the holiest of holy lands. Even so, Surius makes clear that the homeland of Christ is like no other place. This is not a trip, he says, for the idle curiosity seeker. It is a spiritual journey. ${ }^{65}$ Boucher argued, and other friars agreed, that the pilgrimage led straight to the life of Christ. At this point the friars turn to the ancient history of the region to underscore its spiritual uniqueness. Whereas the Italian relazione sometimes evoked the past to justify present-day political decisions and policies, Surius is interested in the spiritual implications of the Christian story. In the Bible the early modern Christian could find guideposts for the salvific journey. Arriving at Jerusalem, Surius tells us that it is time to learn about the region we are entering, and he warns that he will mix history "with a number of sweet thoughts and devotions," indicating that he has more in mind than the 
nostalgic tour of a more perfect epoch. This region, he tells us, in his preacherly Franciscan voice, was the battleground between good and evil. Understanding biblical history, he argues, will enrich the pilgrim on his spiritual quest. He then wishes the reader "all the best and great progress in divine love." ${ }^{66}$

Moral intent aside, Surius's historical retelling becomes yet another way to demarcate the region, and the holy sites in particular, as outside human time and space. The changing state of Palestine from Biblical times to the present day offers a history that began with Abraham and his contract with God for entry to the Promised Land. Once in Jerusalem, Surius devotes even more time to its biblical history. Tracing a long narrative of destruction from the first sacking of the city by the Babylonians through to Saladin's reconquest of the city in 1187 and the subsequent invasion of the Ottomans at the turn of the sixteenth century, the friar finishes by noting the spiritual constancy of the sites. Over 3,580 years he says: "And so was transformed, and so perished... the pearl of cities, and the glory of Palestine. And yet despite these deplorable events and destructions, there remain the principal sites where our Saviour, in his life, was conversant with men...." ${ }^{67}$ Friar Boucher, like Surius, bemoans the historic destruction of Jerusalem, citing as much divine punishment for Christian turpitude as Muslim occupation. The city is in a perilous state, he tells us. It has few magnificent temples except the Holy Sepulcher and the Temple of Solomon, few illustrious buildings except the lodgings of Ottoman officials. It is also "poorly populated with persons of substance, respect and honour." Indeed he has never found, he insists, "so evil, cruel, and pernicious a rabble as lives in the holy city." Once the seat of "sanctity" and "truth," it was now the school of "impiety," "error," and "vanity." 68

When we enter each holy place, the contrast between the mutability of the mundane world outside the walls and the spiritual constancy of Christ becomes especially apparent. The liturgical function of the text remains, but is now given new urgency as our Franciscan authors take time on each visit to recreate the physical sensation of standing in Christ's footsteps. With a passing nod to the fine gifts from worshippers, the friar reverts to the spiritual significance of the site. His account of Christ's last days intermingles with the liturgical evocation of Christ's spiritual authority. The author asks us to look closely at physical manifestations of Christ's presence while recounting the past event that happened at this site. Pilgrims would gather around the rock on which apostles slept in the garden of Gethsemane and listen to the Franciscan preacher's description 
of the Last Supper. At the Holy Sepulchre, the Franciscan guide gestures to the remains of the pillar where Christ was flagellated at Pilate's orders, preaches a sermon, and leads the pilgrims in prayer. At the House of Caiaphas, Boucher asks us to consider Christ's betrayal by his own followers: "It is there at that sad place that our savior, o my soul, was falsely accused, unjustly condemned and shamefully violated, impudently whipped...." But there was no injury more bitter, he insists, than when Christ was "blasphemed and renounced by the treachery of the first of his apostles and disciples." ${ }^{69}$

When combined with the special odour of holiness, the sounds of hushed voices led in prayer and song, and the cries of ecstasy and sorrow emanating from the pilgrims, the reader does not just hear a biblical story often told but sees and experiences it first hand. In this liturgical moment and this particular place, Christ is reliving his last moments on earth. This stark contrast between a contemporary Holy land in fluid imperfection, and the perfect holiness hidden within each site conveyed the continuing spiritual potency of the holy places. It was a Franciscan message that evoked the famous legend of the founder saint who rescued falling churches. Surius tells us that the holy places survived past and present depredations because the region remained a Christian space. The Virgin Mary continued to visit, he tells us, and Christians never really left. ${ }^{70}$ The reader feels in these accounts the palpable presence of Christ himself. Here in the homeland of Christ, the pilgrim steps into a Christian past that is also the present, the future, and eternity. To visit these sites was to experience in all its authenticity the authority of Christ because he, like his mother, never left.

\section{Conclusion}

To what degree, then, can we detect elements of the early modern relation perhaps unconscious, perhaps deliberate - in these Franciscan pilgrim books? How far did they go to meet a new taste for authoritative accounts, from trusted voices, about novel or noteworthy things? The parallels are several. Some of the later travel tales offer a much stronger frame, a clearer account of the narrator's own voyage. And the tales also have devices in their apparatus that establish the figure of the narrator as trusted reporter, with his experiences on the ground and his high religious office and good learning. Moreover, as imaginary guided tours of sacred places, the accounts allow the narrator to lead the mind across 
a dense landscape of sites. The meditative goals of this literature, even so, dilute the significance given by the relation to things of this world by inviting contemplation of things eternal. It would be wrong to expect these Franciscan pilgrim-chroniclers to put out relations. The more interesting question is, to what extent, in a relating world, did they adapt their prose? The answer: more than a little.

\section{Notes}

1. The Jesuit relations are perhaps the most famous example, but we should also consider the growing body of lay-penned accounts flowing from presses throughout the sixteenth and seventeenth centuries. On this varied body of literature, see among others Allan Greer, ed., The Jesuit Relations: Natives and Missionaries in seventeenth-century North America (Boston: Bedford/St Martin's Press, 2000); Frank Lestringant, Le Huguenot et le sauvage. L’Amérique et la controverse coloniale, en France, au temps des Guerres de Religion (1990; rptd Geneva: Droz, 2004); and Joan Pao Rubiès, Travellers and Cosmographers: Studies in the History of Early Modern Travel and Ethnology (London: Ashgate, 2007).

2. Jean Boucher, Le Bouquet sacré composé des plus belles fleurs de la terre sainte, ed. Marie-Christine Gomez-Géraud (Paris: Honoré Champion, 2008), pp. 9-11. Gomez-Géraud has identified thirteen editions of this treatise produced during Boucher's lifetime, and 42 after his death. The scornful voyager was François de la Bouliaye Le Gouz.

3. The scholarship on medieval and early modern pilgrimage narratives is growing at a considerable rate, testifying to the excitement surrounding this once neglected body of sources. A small sampling of some of the most important recent work specifically examining early modern Holy Land narratives includes Wes Williams, Pilgrimage and Narrative in the French Renaissance: "The Undiscovered Country" (Oxford: Oxford University Press, 1998), Marie-Christine Gomez-Géraud, Le Crépuscule du Grand Voyage. Les récits des pèlerins à Jérusalem (1458-1612) (Paris: Champion, 1999), and Thomas F. Noonan, The Road to Jerusalem: Pilgrimage and travel in the age of Discovery (Philadelphia: University of Pennsylvania Press, 2007). See also Frédéric Tinguely, L'Écriture du Levant à la Renaissance: enquête sur les voyageurs français (Geneva: Droz, 2000), and Palmira Brummett, ed., The 
Book of Travels: Genre, Ethnography and Pilgrimage 1250-1700 (Leiden: Brill, 2009).

4. Jean de Thevenot, Relation d'un voyage fait au levant dans laquelle il est curieusement traite des estats sujets au Grand Seigneur, des Mœurs, Religions, Forces, Gouvernemens, Politiques, Langues et Coustumes des Habitans de ce grand Empire (Paris: Louis Billaine, 1665): "Le desir de voyager a tousjours esté fort naturel aux hommes, il me semble que jamais cette passion ne les a pressés avec tant de force qu'en nos jours.... Ce sont ces belles Relations qui m’ont donné la premiere pensée de voyager..." (p. 1). Thevenot would later on travel to Persia and India, dying from a gunshot wound in 1667 . His later voyages were published posthumously.

5. For the sake of simplicity, I will use the term "relation" when making broad comparisons between Holy Land treatises and the more secular forms of travel literature such as the Italian diplomatic relations (relazione) and the account of Thevenot.

6. Megan C. Armstrong, The Politics of Piety: Franciscan Preachers during the French Wars of Religion, 1560-1600 (Rochester: University of Rochester Press, 2004). Chapter 5 discusses in particular the eclectic nature of Franciscan learning, including the influence of humanism. See also Corrie E. Norman, Humanist Taste and Franciscan Values: Cornelio Musso and Catholic Preaching in Sixteenth-Century Italy (Peter Lang: New York, 1998).

7. Henri de Beauvau, Relation journaliere du voyage du levant (Paris, 1610). Beauvau was a companion of Jean de Gontaut Biron, Baron de Salignac, the French ambassador to the Ottoman Porte from 1605 to 1610. Talboon was a member of the Observant convent of Woerschoon. His handwriting situates Talboon in the seventeenth century and he may have been a contemporary of Beauvau. This edition also bears the printed approbation of the guardian and lecturer of the Observant friars of the city of Toul, Fathers Estienne Thadee and Jacques la Frongne.

8. Suriano's Trattato was first written in 1484 and revised significantly later on in $1514 / 5$ and 1524 though only the 1524 version was published. The translation by Bellorini is based on the 1515 manuscript. On the printing history of Bouquet Sacre, see note 2. My research on these Holy Land treatises is ongoing. I have identified at least three other accounts that remain to be consulted, and there are likely more. I still have not been able to consult Jean Dublioul [Du Blioul], le voyage de Hierusalem, for example, which is discussed by Wes Williams among other scholars. 
9. Francesco Suriano, Treatise on the Holy Land, trans. Theophilus Bellorini and Eugene Hoade (Jerusalem: Franciscan Press, 1949).

10. Jean Thenaud, Le voyage d'outremer et itineraire de oultre mer faict par frere Jehan Thenaud, maistre és ars, docteur en theologie et gardien des freres mineurs d'Angousleme, ed. Charles Schefer (rptd, Geneva: Slatkine Reprints, 1971).

11. Harry Charles Luke, ed., A Spanish Franciscan's Narrative of A Journey to the Holy land (London: Palestine Exploration Fund's Office, 1927).

12. Henri Castela, Le guide et adresse pour ceux qui veulent faire le S. Voiage de Hierusalem par V.P.F. Henry Castela Tolosain religieux observantin et confesseur des Dames religieuses a Bordeaux (Paris: chez Laurens Sonnius rue S. Jacques au compas d'or, 1604).

13. Jean Boucher, Le Bouquet sacre compose des plus belles fleurs de la Terre Saincte (Paris: Denis Moreau, 1620).

14. Pacifique de Provins, Le voyage de Perse fait par le p. pacifique (Paris: Nicolas et Jean de la Coste, 1645). This is the second printing of his treatise, the first was around 1631. His voyages took place respectively in 1621-1622, and 1627.

15. Bernardin Surius, Le pieu pelerin ou voyage de Jerusalem divise en trois livres contenans la description topographique de plusieurs Royaumes, pais, villes, nations estrangeres nommement des quatuorze religions orientales, leurs mours \& humeurs, tant en matiere de Religion que de civile conversation \& c. (Brussels, Francois Foppens, 1666).

16. Jacques Goujon, Histoire et voyage de la Terre-Sainte, Où tout ce qu'il y a de plus remarquable dans les Saints Lieux, est tres-exactement descript (Lyon: Pierre Compagnon \& Robert Taillandier, 1670).

17. Wes Williams, Pilgrimage and Narrative in the French Renaissance, and "The Diplomat, the Trucheman and the Mystagogue: Forms of Belonging in Early Modern Jerusalem," in Pilgrim Voices: Narrative and Authorship in Christian Pilgrimage, ed. Simon Coleman and John Eisner (Oxford: Berghahn Books, 2002), pp. 17-39. What is even more intriguing is that both François Rabelais and André Thevet, two other travellers, were former Franciscans. Rabelais left young, and became a bitter critic of the order. Thevet also left at a young age, but kept his affection for the tradition. He would be buried in a Franciscan habit. See Armstrong, The Politics of Piety, ch. 4.

18. Wes Williams, “The Diplomat," p. 19. He cites here the treatise of Jean Dubliol, le voyage de Hierusalem (1602), p. 3. 
19. Continual internal debate over the nature of the Franciscan tradition spawned numerous variations of the tradition by the seventeenth century. Of the three recognized orders, the Observant was then the largest and the Capuchin the most recent (1520). The Conventual was the oldest. The Recollects remained part of the Observant family during the seventeenth century but enjoyed special statutes that set them apart even within this branch. Excellent histories on the evolution of the Franciscan order to the Early Modern period include John Moorman, A History of the Franciscan Order (Oxford: Oxford University Press, 1968), and Duncan Nimmo, Reform and Division in the Franciscan Order (1226-1538) (Rome: Capuchin Historical Institute, 1995).

20. The papal bulls gratias agimus and nuper carissimae (Nov 12,1342) officially recognized the Custody, demarcating an ecclesiastical territory that encompassed the major holy Christian holy sites of Palestine, Syria, and Egypt. The friars were already in Jerusalem, having received a convent in Jerusalem as early as 1333 . Prior to this time, they operated from a convent on the island of Cyprus. For a brief survey, see Martiniano Roncaglia, “The Sons of Saint Francis in the Holy Land," Franciscan Studies 10 (1950), pp, 257-85, and Bernardo Rossi, The Custody of the Holy Land (Jerusalem: Franciscan Printing Press, 1981), pp. 8-15. Without question the most important study of the history of this Franciscan mission is Girolamo Golobovich's masterful multi-volume edition of primary sources, Biblioteca bio-bibliografica della Terra Santa e dell'Oriente Francescano (Quaracchi Collegio di S. Bonaventura, 1906-1927). An excellent dissertation on the organization of the Holy Land pilgrimage during this period of the Custody's history is Béatrice Dansette, "Les pélérinages en terre sainte aux XIVe et XV siècles: Études sur leurs aspects originaux, et Édition d'une relation anonyme” (PhD dissertation: Université de Paris-Sorbonne, 1977).

21. Mamluk and then Ottoman law forbade their evangelization of the Muslim population. For this reason, the Franciscan mission confined itself to the maintenance of the Latin rites in the holy places under Latin jurisdiction. That said, they understood their maintenance of a Latin presence as a form of evangelization. See for example, Oded Peri, Christianity under Islam in Jerusalem: The Question of the Holy Sites in Early Ottoman Times (Leiden: Brill, 2001).

22. Filippo de Vivo, Information and Communication in Venice. Rethinking early Modern Politics (Oxford: Oxford University Press, 2007).

23. Rossi, Custody of the Holy Land, p. 8. 
24. Artistic depictions of Francis as a Second Christ (alter Christus) were common throughout the late medieval period in particular. See for example H. W. van Os, "St Francis of Assisi as a second Christ in early Italian painting," Simiolus: Netherlands Quarterly for the History of Art 7 (1974), pp. 115-32, and James Mundy, "Franciscus alter Christus: The Intercessory Function of a Late Quattrocento Panel," Record of the Art Museum, Princeton University 36 (1977), pp. 4-15.

25. Suriano, p. 19.

26. Suriano, pp. 170-71.

27. “... les enfans de nostre pere S. François, lesquels sont connus de toute la terre par effect, aymez de Vous par election, deffendus par justice, \& chargez de la bienveillance des Empereurs \& des Roys" (Surius, 3v).

28. “... ordure, de saleté \& d'idolatrie, pour en estouffer la memoire, iusqu'à y eriger la statuë d'un Jupiter furieux, \& d'une Venus impudique: \& Saint François est choisi pour reparer ces desordres" (Goujon, pp. 19-20).

29. Goujon, pp. 19-20.

30. Suriano is just one of our authors who list this access to the region as a privilege of all members of the order, in his Treatise, p. 78. However, as discussed later on, access did not necessarily mean the right to go on a mission.

31. The highest Franciscan offices were elected positions. The guardian of a convent was elected for a three-year term, for example. The highest office, Minister General, was a seven-year term. This political structure reflected Franciscan values, notably the spiritual equality of members, their humility, and poverty. Officekeeping was to remain a responsibility and not a possession. On the origins of the Franciscan governance, see Rosalind E. Brooke, Franciscan Government: Elias to Bonaventure (Cambridge: Cambridge University Press, 1959).

32. Thenaud is sufficiently important an author to merit a modern edition of his treatise on the Kabbala. See Jean Thenaud, Traicté de la Cabale, eds. Ian R. ChristieMiller and François Roudaut (Paris: Honoré Champion, 2007).

33. On the transition to Ottoman rule in Palestine, see, among others, Amy Singer, Palestinian Peasants and Ottoman Officials: Rural Administration around sixteenth-century Jerusalem (Cambridge: Cambridge University Press, 1994).

34. Thenaud, Le voyage outremer, pp. lxxiiii-v.

35. Suriano, p. 144.

36. Suriano, p. 157. 
37. Referred to as "Kath Bay" by the friars and described as an "Admiral of 1,000 lances," the Sultan's full name was Al-Ashraf Sayf al-Din Qa'it Bay. The friars tell us he ruled for 38 years. Suriano, p. 126, ft. 1.

38. Suriano, p. 126.

39. Suriano, pp. 129-30.

40. For an excellent analysis of intra-Christian relations during the seventeenth century in particular, see Bernard Heyberger, Les Chrétiens du Proche-Orient au temps de la Réforme Catholique (Rome: École Française de Rome, 1994).

41. Boucher (1620), pp. 193-95.

42. The official name of the Recollect province was "germania inferioris." Surius likely came from the convent in Guelders (Gueldres) since he dedicates the book to the merchants of this city.

43. The routine appointment of friars for the Holy Land mission was discussed at the septennial meetings of the General Chapter of the order. These statutes are collected in the multi-volume document series, Annales Minorum, in Quibus Res Omnes Trium Ordinum a S Francisco Institutorum Ex Fide Ponderiosus Asseruntur, Calumniae Rebelluntur, Praeclara Quaeque Munumenta Ab Oblivione Vendicantur, ed. Lucas Wadding and Francesco Sbaralea (Lyons, 1625).

44. "Vous avez paru en ces Saints lieux que condamné, honteusement voilé, je descries, comme vray heritier de l'authorité \& de la pauvreté de nostre illustre Patriarche, \& mon Coeur est tesmoin pendant trois ans, avec combien de Sainteté \& de zele, vous les avez conservez inviolables." Goujon, dedicatory epistle to friar François Maria Rhini.

45. Goujon, advis au lecteur : "Ce qui me fait admirer, comment nos pelerins qui escrivant de grands volumes de Terre-Sainte, après un mois pour le plus de sejour qu'ils y ont fait, ont crû de pouvoit [sic] dire tout ce qui en est." Thomas Noonan suggests that Goujon may have had pilgrims such as the canon Jean Doubdan (1651-52) in mind, a pilgrim who wrote a very long book based on "brief impressions." F. Thomas Noonan, The Road to Jerusalem (Philadelphia: University of Pennsylvania Press, 2007), p. 206.

46. Surius, p. 284.

47. Virigina Reinburg talks about this liturgical function as the creation of a "psychic space" in her article "Prayer and the Book of Hours," in Time Sanctified. The Book of Hours in Medieval Art and life, ed. Roger S. Wieck (New York: George Braziller, Inc., 1988), p. 44. Her article suggests a psychological study of how early modern 
readers would have used the Holy Land narratives and in particular the sections on the visitation of the sites.

48. Suriano, pp. 53-76.

49. A Spanish Franciscan's Narrative, p. 14. I have not yet been able to locate this village.

50. Henri Castela: "leur clochette, \& les images qu'ils reverent de nostre Seigneur, de la glorieuses vierge Marie sa mere, \& de quelques autres saincts, la ou toutes les nuicts ils vont faire leurs oraisons, presentans devotement leur intention \& zele à Dieu" (f. 14v.).

51. The term "Moor" is taken from the text itself, and was a common early modern designation for different Muslim peoples, though here it may well have referred to those of Arab-North African descent such as the Berber.

52. Castela devotes over 40 folio pages to a description of Cairo (ff. 400-40). Jean-Paul Bonnin finds this interest in Cairo characteristic of early modern pilgrimage accounts. Cairo both excited and disturbed these travellers, who saw in it the ancient world of Christ but also manifestations of contemporary Muslim decadence. Bonnin, "Les pèlerins de Jérusalem dans les villes musulmanes. Du rejet systématique à la difficile séduction," Publications de la Sorbonne 1 (2003), pp. 87-97.

53. Castela writes that heretics "ne conserve ny revere les temples qu'il prent sur les catholiques, ains les ayans pillés \& de toute sorte prophanés, les brusle, abat \& rase de font en comble, sans faire cas ny compte de ces beaux \& honorables titres que Jesus Christ mesme leur a donné...” (f. 37).

54, “... vouland dechiffrer la diversité des peoples Outre-marins, tant en matiere de Religion que de police..." (Surius, dedicatory epistle, 2v.).

55. Surius, p. 10.

56. "J'y regardois tous ces lieux desolez avec un oeil bien triste, les places frontieres tant du Païs-Bas que de la France entierement ruinées, les Eglises bruslées, les Chateaux terrassez, \& les Villages abandonnez, effets pitoyables de la guerre" (Surius, p. 11).

57. Surius, p. 17.

58. For example, Surius arrived in Paris on May 3, 1644. Here, at the famous Franciscan studium (theology school), he met a fellow Flemish friar named Didac Chrestien, who had been a novice with him at the convent of Bootendal and a fellow student of Philosophy and Theology (Surius, pp. 14-15).

59. Boucher (1620), pp. 132-133. The complete passage conveys the underlying Franciscan meaning of Boucher's metaphorical usage of Jerusalem as a trope of Chris- 
tian moral and spiritual degradation. Muslims were not the only ones responsible for tarnishing Christian purity, in other words. "Mais helas! Mes esperances ont estée vaines \& trompeuses, car j’ay trouvé une ville telle que la depeinct le dolent \& pleureux Jeremie en ses Lamentations souspirantes, sçavoir est solitaire, assise en tristesse, couverte de mespris, environnee de tenebres, despoüillee de gloire \& d'honneur, destituee de toute assistance, vefve de tous plaisirs, delaissee de ses enfans, mocquee de ses nourrissons, mesprisee des passans, des-honoree par les etrangers, out rageusement offencee par des incogneus, oppressee par des barbares inhumains, prophanee par des sacrileges, abandonnee des Monarques \& des Roys, negligee des Princes \& Seigneurs, repudiee des siens propres, \& privee de toute consolation: laquelle ne cessant de pleurer nuict \& jour, demeure toute seule sans loy, sans foy, sans Prestre, sans Sacrifice, sans Autel, sans roy, sans Prince, sans Magistrat, sans Docteur \& sans Juge."

60. Noonan for one discusses this pessimistic perception of Jerusalem in the wake of the Reformation, but it is important also to note that it was a common trope in medieval pilgrimage tales. See among others, DC Howard, Writers and Pilgrims: Medieval Pilgrimage Narratives and their Posterity (Berkeley: University of California Press, 1980) and more recently Suzanne Yeager, Jerusalem in Medieval Narrative (Cambridge: Cambridge University Press, 1998).

61. On the material nature of Franciscan spirituality, see in particular David Burr, The Spiritual Franciscans: from Protest to Persecution in the century after Saint Francis (Penn State Press, 2001). See also Megan C. Armstrong, "A Franciscan Kind of Hell: Torture, Love and Redemption in Early Modern French Franciscan sermons," in Hell and Its Afterlife, ed. Isabelle Moreira and Margaret Toscano (Farnham: Ashgate, 2010).

62. 'C'est un lieu le plus admirable du monde, tant pour sa solitude, hauteur, que pour la penitence que cette S. Amante de Jesus y fit, y trouvant tout contentement...” (Surius, p. 27).

63. "Mais si vous estes dans le monde, visitez vostre chambre pour le moins une fois ou deux le jour, au lieu de vous mettre par curiosité à la porte, ou à la fenestre pour voir ce e qui se passé sur les rues, ou dans le jardin; retirez vous en vostre cabinet pour y prier, pour penser à Dieu, pour avoir conte de vostre salut, pour lire quelque livre spirituel, pour faire le petit hermite" (Surius, pp. 29-30).

64. 'Qu'estimez vous vostre cellule? Selon S Bernard, c'est un petit Paradis: de la cellule on monte au Ciel, la cellule est un Païs saint, \& un lieu où l'ame se joint avec Dieu" (Surius, p. 30). 
65. Surius, p. 285.

66. Surius, p. 285. The complete passage is the following: "Ne trouvez pas estrange si j'entrelasse ce discours historique cy \& là de quelques douces pensées \& devotions: car il faut penser que le voyage de la Terre Sainte differe d'avec les autres en ce que ceux-là si font ordinairement par curiosité ou par utilité: mais cestuy cy qui conduit en la Palestine, ou la puissance, sapience \& bonté divine a combattu l'orgueil, la folie, \& la malice du monde, ne se fait que sous l'esire d'un profit spirituel, qui consiste en l'accroissement de devotion \& foy... En finissant, je vous souhaitte tout bien, \& un grand progrés en l'amour Divin."

67. “Ainsi fut metamorphosé, \& perit l'oeil du monde, le Diademe des Royaumes, la perle des Villes, \& la gloire de Palestine. Et nonobstant tous ces deplorables evenemens \& destructions, resterent encore tous les lieux principaux où Nostre Sauveur durant sa vie conversa entre les homes, sçavoir où il a presché, où il fut crucifié, ensevely, où il resuscits, \& monta au Ciel, \&." (Surius, p. 370).

68. "Mais tout ainsi que ceste saincte ville est mal ornee de superbes bastimens; Aussi elle est mal peuplee de gens de bien, de respect \& d'honneur; Car je croy que d'icy là ne se pourra trouver une si meschante, cruelle, \& pernicieuse canaille que celle là qui habite ceste Cité saincte, comme si Dieu par un secret jugement vouloit permettre que ceste ville sacree, qui jadis fut lie siege de saincteté, soit maintenant le sejour d'impieté, \& celle qui fut jadis la chaire de verité, soit maintenant l'eschole d'erreur, de mensonge \& de vanité" (Boucher [1620], p. 181).

69. “Cest donc là le triste lieu où ton Sauveur, ô mon ame, a esté faussement accusé, iniquement adjuré, injustement condamné, honteusement voilé, malheureusement frappé, impudemment souffletté... Mais tous ces déplaisirs ne luy ont point esté si amers que celuy qu'il receut lors qu'il se vid si malheureusement blasphemé \& renoncé par la lascheté du premier de ses Apostres \& Disciples..." (Boucher [1620], pp. 216-7).

70. Surius, p. 379. 